\title{
URGENSI KECERDASAN EMOSIONAL BAGI ANAK USIA DINI
}

\author{
Rika Sa'diyah \\ (Dosen Fakultas Ilmu Pendidikan Universitas Muhammadiyah Jakarta)
}

\begin{abstract}
ABSTRAK
Tidak sedikit anak yang cerdas secara akademis gagal dalam kehidupan sosial dan lainnya. Artinya, terdapat faktor lain di luar kecerdasan intelektual yang menunjang keberhasilan anak dalam kehidupannya. Kecerdasan intelektual dan kecerdasan non-intelektual berperan sama penting dalam menunjang kesuksesan individu, kemampuan non-intelektual sangat penting untuk memprediksi kemampuan individu dalam mencapai kesuksesan hidup.

Kemampuan IQ dan EQ sama penting dan saling menunjang, meski keduanya memiliki cara kerja yang berbeda. Tentu yang diharapkan adalah bukan kemampuan salah satunya tetapi keseimbangan antara keduanya. Kecerdasan yang memungkinkan manusia berpikir rasional, logis, dan taat asas dinamakan kecerdasan intelektual. Sementara itu, kecerdasan lain yang memungkinkan manusia berpikir asosiatif, yang terbentuk oleh kebiasaan dan kemampuan mengenali pola-pola emosi, dinamakan kecerdasan emosional. Banyak anak mengalami hambatan dalam belajar karena faktor-faktor non-intelektual dan semua yang manusia lakukan dikendalikan oleh emosi.
\end{abstract}

Kata-kata kunci: Kecerdasan, Emosi, Kecerdasan Emosional, AUD

\section{A. PENDAHULUAN}

Pendidikan merupakan hal yang essensial dalam hidup dan kehidupan manusia karena proses pendidikan berada dan berkembang bersama perkembangan hidup manusia. "Life is education and education is life"1 merupakan gambaran bahwa manusia tidak bisa memisahkan pengalaman hidupnya dari pengaruh pendidikan dan sebaliknya. Oleh karena itu, dalam sistem pendidikan nasional di Indonesia dirumuskan tujuan pendidikan yaitu mencerdaskan bangsa dan mengembangkan

\footnotetext{
${ }^{1}$ Ruper C. Lodge, Philosophy of Education (New York: Harer and Brothers, 1974), p. 23.
} 
manusia Indonesia seutuhnya ${ }^{2}$ sebagai perwujudan bahwa pendidikan berperan dalam perkembangan hidup manusia.

Tujuan pendidikan nasional yang diuraikan di muka menjadi modal dasar untuk menyiapkan insan yang berkualitas. Untuk menciptakan insan Indonesia yang berkualitas ini, sistem pendidikan harus berupaya mengendalikan pemerataan kesempatan pendidikan secara serasi, selaras dan seimbang serta berlangsung sepanjang hayat. Hal ini menandakan bahwa pendidikan harus dilakukan sejak usia dini.

Pentingnya pendidikan anak usia dini telah banyak diteliti oleh para ahli. Satu diantaranya Lindsey dalam Arce menyatakan bahwa perkembangan jaringan otak dan periode perkembangan kritis secara signifikan terjadi pada tahun-tahun usia dini, dan perkembangan tersebut sangat ditentukan oleh lingkungan dan pengasuhan. ${ }^{3}$ Lingkungan dalam pengertian ini menurut Shore dalam Arce sebelum anak lahir, saat pembentukan otak anak terjadi. ${ }^{4}$

Berdasarkan penelitian di bidang neurologi yang dilakukan oleh Baylor College of Medicine membuktikan bahwa apabila anak jarang memperoleh rangsangan pendidikan, maka perkembangan otaknya lebih kecil 20-30\% dari ukuran normal anak seusianya. Penelitian juga menyatakan bahwa 50\% kapasitas kecerdasan manusia sudah terjadi ketika anak berumur 4 tahun, $80 \%$ telah terjadi ketika berumur 8 tahun. $^{5}$

Kenyataan ini memperkuat keyakinan bahwa pendidikan bagi anak seyogyanya dimulai sedini mungkin, tidak hanya di usia pendidikan dasar 9 tahun dimana setelah sebagian besar kemungkinan pengembangan potensi anak mulai berkurang. Artinya apabila pendidikan baru dilakukan pada usia 7 tahun atau sekolah

\footnotetext{
${ }^{2}$ Pasal 4 Undang-undang RI Nomor 20 Tahun 2003 tentang Sistem Pendidikan Nasional.

${ }^{3}$ Eve-Marie Arce, Curriculum for Young Children: An Introduction (New York: Delmar Thomson Learning, 2000), p. 7.

${ }^{4}$ Ibid., p. 8.

${ }^{5}$ Direktorat PAUD, Tantangan yang Harus Dijawab (Jakarta: Buletin PADU Jurnal Ilmiah Anak Usia Dini, 2002), p. 2.
} 
dasar stimulasi lingkungan terhadap fungsi otak yang telah berkembang $80 \%$ tersebut terlambat dalam pengembangannya.

Sejak dipublikasikan hasil-hasil riset mutakhir di bidang neuroscience dan psikologi di atas, maka fenomena pentingnya pendidikan anak usia dini merupakan keniscayaan. Pendidikan anak usia dini menjadi sangat penting mengingat potensi kecerdasan dan dasar-dasar perilaku seseorang terbentuk pada rentang usia ini. Sedemikian pentingnya masa ini sehingga usia dini sering disebut the golden age (usia emas).

Pendidikan anak usia dini merupakan pendidikan yang paling mendasar menempati posisi yang sangat strategis dalam pengembangan sumber daya manusia. Rentang anak usia dini adalah dari lahir sampai delapan tahun merupakan rentang usia kritis dan sekaligus strategis dalam proses pendidikan yang dapat mempengaruhi proses serta hasil pendidikan pada tahap selanjutnya. Periode ini merupakan periode kondusif untuk menumbuhkembangkan berbagai potensi kecerdasan karena karunia terbesar yang Allah SWT berikan kepada manusia, salah satunya adalah kecerdasan. Kecerdasan membedakan manusia dari makhluk-makhluk lain. Kecerdasan termasuk aspek psikologis yang dapat mempengaruhi kesuksesan individu atau keberhasilan individu dalam belajar. ${ }^{6}$

Dewasa ini dikenal bukan hanya kecerdasan intelektual (IQ) yang dapat mengantarkan seseorang pada keberhasilan, melainkan juga kecerdasan-kecerdasan lain. Secara garis besar, kecerdasan dipilah jadi kecerdasan intellective dan nonintellective. ${ }^{7}$ Kecerdasan intellective atau intelektual disebut juga dengan kecerdasan kognitif, sedangkan kecerdasan non-intellective atau non-intelektual meliputi kecerdasan-kecerdasan di luar kecerdasan kognitif. Salah satu kecerdasan nonintelektual ialah kecerdasan emosional.

Kecerdasan intelektual dan kecerdasan non-intelektual berperan sama

\footnotetext{
${ }^{6}$ Muhibbin Syah, Psikologi Pendidikan dengan Pendekatan Baru (Bandung: Rosda Karya, 2000), p. 133.

${ }^{7}$ Cary Cherniss, Emotional Intelligence: What it is and What it Matters, p. 2, 2008 (www.Eiconsortium.org).
} 
penting dalam menunjang kesuksesan individu. Namun, Wechsler menyatakan bahwa kemampuan non-intelektual sangat penting untuk memprediksi kemampuan individu dalam mencapai kesuksesan hidup. ${ }^{8}$

Kemampuan IQ dan EQ sama penting dan saling menunjang, meski keduanya memiliki cara kerja yang berbeda. Dalam dunia corporate sering terdengar istilah, IQ gets you hired, but EQ gets you promoted. ${ }^{9}$ Tentu yang diharapkan adalah bukan kemampuan salah satunya tetapi keseimbangan antara keduanya. Kecerdasan yang memungkinkan manusia berpikir rasional, logis, dan taat asas dinamakan kecerdasan intelektual. Sementara itu, kecerdasan lain yang memungkinkan manusia berpikir asosiatif, yang terbentuk oleh kebiasaan dan kemampuan mengenali polapola emosi, dinamakan kecerdasan emosional. ${ }^{10}$

Kecerdasan emosional termasuk dalam kecerdasan personal yang merupakan bagian dari kecerdasan majemuk (multiple intelligences) yang dikemukakan oleh Howard Gardner. Kecerdasan personal meliputi kecerdasan intrapersonal dan interpersonal. Goleman mengembangkan kecerdasan emosional (emotional intelligence) atau EI yang menitikberatkan pada kecerdasan pribadi (personal intelligence). ${ }^{11}$

Banyak anak mengalami hambatan dalam belajar karena faktor-faktor nonintelektual. Daniel Goleman mengatakan bahwa orang yang mengalami gangguan emosional tidak bisa mengingat, memperhatikan, belajar, atau membuat keputusan secara jernih karena gangguan emosional (stres) membuat orang jadi tumpul. ${ }^{12}$ Candace dalam Given menyatakan bahwa emosi menghubungkan tubuh dengan otak dan menyediakan energi untuk memacu prestasi akademis, kesehatan dan

\footnotetext{
${ }^{8}$ D.Wechsler, Non-Intellective Factors in General Intelligence, p. 3, 2008 (www.eiconsortium.org).

${ }^{9}$ Nancy Gibbs, The EQ Factor, (www.timereports undestandingpsychology).

10 Danah Zohar dan Ian Marshall, Spiritual Intelligence: The Ultimate Intelligence (London: Bloomsbury Publishing, 2000), p. 6.

${ }^{11}$ Daniel Goleman, Kecerdasan Emosional, terjemahan T. Hermaya (Jakarta: Gramedia, 2003), p. 57.

${ }^{12}$ Daniel Goleman, Emotional Intelligence: Why it Can Matter More Than IQ (New York: Bantam Books, 1995), p. 149.
} 
keberhasilan pribadi. Semua yang manusia lakukan, dikendalikan oleh emosi. ${ }^{13}$

Anak-anak yang memiliki kecerdasan emosional tinggi artinya memiliki kemampuan yang terdapat dalam unsur-unsur kecerdasan emosional, yakni kemampuan untuk mengontrol dan mengelola emosi, bersikap empati, memiliki keterampilan dalam hubungan sosial, memotivasi diri, mandiri, bertanggung jawab, tahan terhadap stres, optimis, dan kemampuan memecahkan masalah. Komponenkomponen kecerdasan emosional ini mendukung kesuksesan hidup kelak dikemudian hari setelah mereka dewasa.

Mengingat pentingnya memiliki kecerdasan emosional, maka kecerdasan harus diajarkan kepada anak sedini mungkin. Goleman menuliskan pentingnya mengajarkan kecerdasan emosional kepada anak-anak untuk memberikan kesempatan yang lebih baik kepada mereka dalam rangka memanfaatkan potensi yang mereka miliki. ${ }^{14}$ Maka berikut ini akan dibahas beberapa hal yang terkait, diantaranya pengertian kecerdasan emosional, perkembangan emosi anak usia dini, kemudian seberapa penting mengajarkan kecerdasan emosi bagi seorang anak dan diakhiri dengan kesimpulan.

\section{B. PENGERTIAN KECERDASAN EMOSIONAL}

Kecerdasan menyangkut kemampuan menyelesaikan masalah yang merupakan kemampuan umum mental individu yang tampak dalam caranya bertindak dan melaksanakan suatu pekerjaan. Kecerdasan juga ditunjukkan melalui kecepatan, ketepatan dan keberhasilan dalam berbuat atau memecahkan masalah yang dihadapi. Oleh karena itu, makin tinggi taraf kecerdasan seseorang akan makin cepat, makin tepat dan makin berhasil ia dalam bertindak atau memecahkan masalah.

\footnotetext{
13 Barbara K. Given, Brain-Based Teaching; Merancangkan Kegiatan Belajar Mengajar yang Melibatkan Otak Emosional, Sosial, Kognitif, Kinestetis, dan Reflektif, terjemahan Lala Herawati Dharma (Bandung: Mizan, 2007), p. 38.

${ }^{14}$ Daniel Goleman, Kecerdasan Emosi untuk Mencapai Puncak Prestasi, terjemahan Alex Tri Kuntjoro (Jakarta: Gramedia Pustaka Utama, 2000), p. 512.
} 
Emosi sebagai aspek psikologis individu menjadi dasar dalam memahami kecerdasan emosi secara lengkap, bagaimana emosi mampu meningkatkan prestasi, kinerja atau menggapai kesuksesan dalam hidup dan bagaimana emosi dapat dikelola menjadi emosi yang cerdas. Dengan demikian memahami emosi menjadi langkah awal dalam memahami hakikat kecerdasan emosional. Karena itu selanjutnya akan dijelaskan pengertian kecerdasan, emosi serta kecerdasan emosional.

Piaget dalam Hagenhan dan Oslon mendefinisikan kecerdasan sebagai: An intelligent act is one cause an approximation to the conditions optimal for an organism's survival. In other word's, intelligence allows an organism to deal effectively with its environment. ${ }^{15}$ Pengertian tersebut menjelaskan bahwa inteligensi merupakan tindakan yang menyebabkan perhitungan atas kondisi-kondisi secara optimal bagi organisme agar dapat bertahan hidup. Dengan perkataan lain inteligensi menciptakan organisme untuk dapat hidup dengan lingkungan secara efektif. Pendapat serupa dikemukakan Wechler dalam Lefton bahwa inteligensi adalah totalitas kemampuan seseorang untuk bertindak dengan tujuan tertentu, berpikir secara rasional, serta menghadapi lingkungan dengan efektif. ${ }^{16}$

Secara sederhana Henmon mengartikan inteligensi adalah daya atau kemampuan untuk memahami. ${ }^{17}$ Namun demikian, sesungguhnya kecerdasan tidak dapat diartikan sesederhana itu, karena kecerdasan ditunjukkan melalui bagaimana seseorang dapat menyelesaikan masalah yang terjadi dalam kehidupan. Gardner merumuskan kecerdasan sebagai kemampuan menyelesaikan masalah, atau menciptakan produk yang merupakan konsekuensi dalam suasana budaya atau masyarakat tertentu. ${ }^{18}$

Dengan demikian, dapat disimpulkan bahwa kecerdasan merupakan sebuah gambaran kemampuan rasional individu yang di dalamnya memiliki unsur-unsur

\footnotetext{
${ }^{15}$ B.R. Hagenhan and Matthew J. Oslon, An Introduction to Theories of Learning (New Jersey: Prentice-Hill, Inc., 1997), p. 281.

${ }^{16}$ Lester A. Lefton, Psychology (Boston: Allyn \& Bacon, 1997), p. 267.

${ }^{17}$ Ibid., p. 268.

${ }^{18}$ Howard Gardner, Multiple Intelligence, Kecerdasan Majemuk:Teori dan Praktek, terjemahan Alexander Sindoro (Jakarta: Interaksara, tanpa tahun), p. 34.
} 
yaitu kemampuan mengarahkan pikiran atau mengarahkan tindakan serta kemampuan untuk mengubah diri sendiri atau autokritik. Karena itu, seorang yang cerdas mengoptimalkan rasionalnya sehingga mampu berpikir cepat dan tepat. Serta hal lain yang mencirikan seseorang cerdas yaitu kemampuan dalam menyesuaikan diri dengan masalah, ia mampu melakukan pemecahan masalah yang efektif dan efisien.

Sedangkan untuk memahami emosi terdapat beberapa penjelasan pengertian tentang emosi. Emosi adalah satu keadaan yang terangsang dari organism, mencakup perubahan-perubahan yang disadari, yang mendalam sifatnya, disertai perubahan perilaku. ${ }^{19}$ Karena itu timbulnya emosi merupakan stimulus eksternal, misalnya kecemasan merupakan reaksi emosi karena sesuatu terjadi diluar harapan individu, yang justru menimbulkan masalah baru bagi dirinya sendiri. Emosi juga merujuk pada suatu perasaan dan pikiran-pikiran khasnya, yaitu suatu keadaan biologis dan psikologis serta serangkaian kecenderungan untuk bertindak. ${ }^{20}$ Artinya emosi tidak hanya melibatkan aspek psikologis tetapi juga aspek biologis. Hal ini juga dapat terlihat ketika seseorang sedang marah biasanya diiringi dengan perubahan fisik, seperti gemetar, mata memerah dan sebagainya.

Emosi pada dasarnya sesuatu yang kompleks karenanya sulit untuk dijelaskan. Namun demikian, ketika emosi terjadi sesungguhnya terdapat komponen emosi yang dapat dijelaskan yaitu meliputi: 1) respons tubuh internal, terutama yang melibatkan sistem saraf otonomik, 2) keyakinan atau penilalain kognitif bahwa telah terjadi keadaan positif atau negatif tertentu, 3) ekspresi wajah, 4) reaksi terhadap emosi. $^{21}$

Ketika mengalami suatu emosi yang kuat seperti rasa takut atau marah sesungguhnya telah terjadi perubahan pada tubuh seperti rasa kering di tenggorokan dan mulut, berkeringat dan pernapasan yang cepat. Sebagian perubahan fisiologis

\footnotetext{
19 Chaplin. J.P, Kamus Lengkap Psikologi, terjemahan Kartini Kartono (Jakarta: Raja Grafindo Persada, 2011), p. 163.

20 Daniel Goleman, Kecerdasan Emosional, terjemahan T. Hermaya (Jakarta: Gramedia Pustaka Utama, 2003), p. 410.

${ }^{21}$ Rita L. Atkinson, Pengantar Psikologi, terjemahan Widjaja Kusuma (Batam: Interaksara, 1987), p. 87.
} 
yang terjadi selama rangsangan emosional terjadi akibat aktivasi cabang simpatik dari sistem saraf otonomik untuk mempersiapkan tubuh melakukan tindakan darurat. Karena itu, kerja emosi sangat berkaitan dengan otak tertentu yaitu sistem limbik. Dalam sistem limbik terdapat amigdala yang merupakan spesialis masalah-masalah emosional. $^{22}$

Goleman mengungkapkan bagaimana arsitektur otak memberi tempat istimewa bagi amigdala sebagai penjaga emosi, penjaga yang mampu membajak otak ${ }^{23}$ karena amigdala mampu mengambil alih kendali apa yang kita kerjakan bahkan sewaktu otak yang berpikir atau neokorteks masih menyusun keputusan. Fungsi amigdala dan pengaruhnya pada neokorteks inilah merupakan inti kecerdasan emosional.

Dari uraian tersebut, dapat disimpulkan bahwa emosi dapat terarah ketika masuk dalam proses kognisi atau bila masuk korteks, namun sebaliknya emosi juga bisa tak terkendali, liar, dan spontan manakala terjadi pembajakan emosi, yaitu ketika amigdala mengambil peran. Karena itu, menyelaraskan emosi dan nalar atau kerja sama antara sistem limbik dengan neokorteks akan meningkatkan kecerdasan emosional. Artinya seseorang mampu menggunakan emosinya secara cerdas.

Kecerdasan sesungguhnya tidak hanya menekankan pada aspek kognitif seperti aspek memori dan problem solving, jauh sebelumnya peneliti telah membangun pengetahuan penting mengenai aspek non-cognitive, dan pada awal tahun 1920 telah menggunakan istilah social intelligence untuk menggambarkan kemampuan dalam memahami dan mengelola orang lain. Kemudian pada tahun 1940, David Wechler menggambarkan pengaruh faktor non-intellective pada perilaku

\footnotetext{
${ }^{22}$ Ibid., p. 89.

${ }^{23}$ Daniel Goleman, op.cit., p. 23.
} 
kecerdasan $^{24}$ tahun 1983 Howard Gardner memperkenalkan ide multiple intelligences yang antara lain meliputi aspek kecerdasan intrapersonal dan interpersonal. ${ }^{25}$

Adapun istilah kecerdasan emosional (emotional intelligence) pada awalnya dilontarkan oleh Wayne Payne (1985) dalam disertasi yang membahas tentang emosi. Selanjutnya Peter Salovey dari Universitas Harvard, dan John Mayer dari Universitas New Hampshire, juga menggunakan istilah ini kemudian dipopulerkan oleh Daniel Goleman lewat bukunya Emotional Intelligence: "Why It Can Matter More Than IQ”, ${ }^{26}$ Salovey \& Mayer mengemukakan definisi kecerdasan emosional sebagai berikut:

"A type of emotional information processing that includes accurate appraisal of emotions in one self and others, appropriate expression of emotion, and adaptive regulation of emotion in such a way as to enhance living". ${ }^{27}$

Artinya kecerdasan emosional sebagai sejumlah keterampilan yang berhubungan dengan keakuratan penilaian tentang emosi diri sendiri dan orang lain, serta kemampuan mengelola perasaan untuk memotivasi, merencanakan, dan meraih tujuan kehidupan.

Dalam menjabarkan arti kecerdasan emosional, Salovey \& Mayer menggunakan pengertian "personal intelligence” yang dikemukakan oleh Gardner sebagai definisi dasar yakni kemampuan untuk memahami orang lain, apa yang memotivasi, serta cara bekerja sama dengan mereka. Juga kemampuan untuk membedakan dan menanggapi dengan tepat suasana hati, temperamen, motivasi, dan hasrat orang lain.

\footnotetext{
${ }^{24}$ Cary Charniss. Emotional Intelligence: What it is and Why it Matters, on Paper Presented at the Annual Meeting of the Society for Industrial Organizational Psychology, New Orleans, p. 2, 2008 (www.eiconsortium.org).

${ }^{25}$ Howard Gardner, Frames of Mind (New York: Basic Books 1983), p. 5.

${ }^{26}$ W.L. Payne, A Study of Emotion: Developing Emotional Intelligence, Self Integration, Relating to Fear, Pain and Desire. (Dissertation Abstracts International: University Microfilms 47), p. 203A, 2008. (http//EI_artikel/Emotional_intelligence_wikipedia.htm).

27 Peter Salovey \& J.D. Mayer, Emotional Intelligence, p. 2, 2008. (http://unh.edu/emotional_intelligence/EIAssets/Emotional_Intelligence_Proper/Emotional_Imaginati on, Cognition, and Personality).
} 
Pengertian serupa juga dikemukakan oleh Goleman yang mengartikan emotional intelligence sebagai: "It is the capacity for recognizing our own feelings and those of others, for motivating ourselves, and for managing semotions well in ourselves and in our relationships". ${ }^{28}$ Artinya kecerdasan emosional adalah kemampuan mengenali perasaan diri dan orang lain, kemampuan memotivasi diri sendiri, dan kemampuan mengelola emosi dengan baik pada diri sendiri dan dalam hubungan dengan orang lain. Goleman menjabarkan kecerdasan emosional dalam beberapa ranah yakni; kesadaran emosi diri, mengelola emosi, motivasi diri, empati dan hubungan sosial.

Pengertian selanjutnya dikemukakan Patton, bahwa kecerdasan emosional adalah kekuatan dibalik singgasana kemampuan intelektual yang merupakan dasardasar pembentukan emosi yang mencakup keterampilan-keterampilan seperti: menunda kepuasan dan mengendalikan impuls-impuls, tetap optimis jika berhadapan dengan kemalangan dan ketidakpastian, menyalurkan emosi-emosi yang kuat secara efektif, mampu memotivasi dan menjaga semangat disiplin diri dalam usaha mencapai tujuan, menangani kelemahan-kelemahan pribadi, menunjukkan rasa empati kepada orang lain, membangun kesadaran diri dan pemahaman diri. ${ }^{29}$

Adapun pengertian kecerdasan emosional yang diungkapkan oleh Bar-On sebagai berikut; "Emotional Intelligence is a multifactorial array of interrelated emotional, personal, and social abilities that help us cope with daily demand"30. Artinya, kecerdasan emosional merupakan serangkaian kemampuan atau sekumpulan kecakapan yang saling berhubungan dan membantu seseorang untuk berhasil mengatasi tuntutan dan tekanan lingkungan. Kumpulan kecakapan tersebut dikelompokkan dalam lima ranah yakni: 1) ranah intrapribadi, yang di dalamnya terdapat kemampuan mengenal emosi diri, sikap asertif, kemandirian, penghargaan

\footnotetext{
${ }^{28}$ Daniel Goleman, Emotional Intelligence Why It Can Matter More Than IQ (New York: Bantam Books, 1995), p.149.

${ }^{29}$ Patricia Patton, EQ: Landasan untuk Meraih Sukses Pribadi dan Karir, terjemahan. Hermes (Jakarta: Mitra Media, 2000), p.10.

${ }^{30}$ Steven J Stein \& Howard E. Book, Ledakan EQ, 15 Kecerdasan Emosional Meraih Sukses, terjemahan Tri Nanda \& Yudi M (Bandung: Kaifa, 2002), p. 10.
} 
diri dan aktualisasi diri, 2) ranah interpribadi, yang terdiri dari kemampuan berempati, tanggung jawab sosial dan hubungan antar pribadi, 3) ranah penyesuaian diri, terdiri dari kemampuan memecahkan masalah, uji realitas dan sikap fleksibel, 4) ranah penanganan stres, terdiri dari ketahanan menanggung stres dan pengendalian impuls, dan 5) ranah suasana hati umum, terdiri dari kebahagiaan dan optimisme.

Beberapa pengertian lain mengenai kecerdasan emosional yang merupakan hasil penelusuran di website sebagai berikut: emotional intelligence adalah, an individual's ability to manage him or herself as well as other. ${ }^{31}$ Kecerdasan emosional merupakan kemampuan individu dalam mengatur diri dan orang lain. Berikutnya, emotional intelligence diartikan, the awarenes of and ability to manage one's emotions in a healthy and productive manner. ${ }^{32}$ Kesadaran dan kemampuan untuk mengatur emosi dengan cara yang sehat dan produktif. Lebih lanjut bahwa, emotional intelligence adalah the ability, capacity, or skill to perceive, assess, and manage the emotions of one's self, of others, and of groups. ${ }^{33}$ Artinya bahwa kecerdasan emosional adalah kemampuan untuk menerima, menilai dan mengatur emosi diri, orang lain dan kelompok. Artinya emosi dikelola sehingga menjadi produktif, tidak hanya emosi diri tetapi juga orang lain dan kelompok.

Dari beberapa pengertian di atas, maka dapat dipahami bahwa kecerdasan emosional itu adalah sekumpulan kemampuan individu yang saling berhubungan dalam hal bagaimana mengenali, menghargai diri sendiri, dan mampu mewujudkan potensi diri. Memahami emosi orang lain, sehingga dapat bersikap empati, mampu bekerja sama dalam kelompok, dan mampu menciptakan hubungan yang harmonis, mampu menyesuaikan diri serta mampu mengendalikan stres. Menghasilkan suasana hati umum yang penuh optimis dan kebahagiaan, yang pada akhirnya mengantarkan individu pada sebuah perilaku berupa cara kerja yang baik. Dalam kehidupan seorang anak selaku individu yang memiliki kecerdasan emosional tinggi tentu dapat

\footnotetext{
${ }^{31}$ Anonymous, Emotional Intelligence, p. 3, 2008 (www.case.edu/med/epidbio/mphp439/ dictionary.htm).

${ }^{32}$ Anonymous, Emotional Intelligence, p. 2, 2008 (Allpsych.com/dictionary/dictionary2.html).

${ }^{33}$ Anonymous, Emotional Intelligence, p. 3, 2008 (En.wiktionary.org/wiki/emotional. intelligence).
} 
menangani stres sehingga menjadi mental yang sehat. Sebaliknya bagi individu yang memiliki kecerdasan emosional rendah tentu ia mudah menjadi sakit, depresi dan tidak berkonsentrasi dalam bermain maupun belajar.

Secara garis besar dapat dijelaskan bahwa, kecerdasan emosional bukanlah sesuatu yang ada atau tidak ada ketika anak baru dilahirkan, kecerdasan emosional harus diajarkan dan dibina selama tahap pendewasaan seorang anak karena apabila dibiarkan tanpa diajarkan, anak kemungkinan berkelakuan dengan cara-cara yang tidak dapat diterima oleh masyarakat. Kecerdasan emosional meliputi kemampuan menerima, mengekspresikan, memahami dan mengelola emosi dan mampu memberikan kontribusi dalam menghadapi kejadian-kejadian dalam kehidupan kelak di kemudian hari, dan pada akhirnya dengan kemampuan kecerdasan emosional nantinya anak dapat menghasilkan persahabatan yang berkualitas, kesehatan fisik dan mental, kesuksesan di dunia kerja maupun di sekolah.

\section{PERKEMBANGAN EMOSI ANAK USIA DINI}

\section{Pengertian Anak Usia Dini}

Ditinjau dari sisi usia kronologis, anak usia dini adalah kelompok anak yang berada pada rentang usia 0-8 tahun menurut kesepakatan UNESCO, serta dalam pandangan umum anak diartikan sebagai seseorang baik laki-laki maupun perempuan yang belum mencapai umur dewasa. Secara normatif, anak diartikan seseorang yang lahir sampai usia enam tahun. ${ }^{34}$

Perbedaan rentang usia antara UNESCO dan Undang-undang Republik Indonesia tahun 2003 tentang Sistem Pendidikan Nasional di atas adalah terletak pada prinsip pertumbuhan dan perkembangan anak, dimana usia 6-8 tahun merupakan usia transisi dari masa anak-anak yang masih memerlukan bantuan (dependen) ke masa anak-anak yang mulai mampu mandiri (independen), baik dari segi fisik, mental, sosial, intelektual maupun emosional. Oleh sebab itu, UNESCO

\footnotetext{
${ }^{34}$ Pasal 1 ayat 14 Undang-undang No.23 Tahun 2003 tentang Sistem Pendidikan Nasional.
} 
menetapkan bahwa rentang usia anak 0-8 tahun masih berada pada jalur Early Childhood Education atau PAUD. Sedangkan dalam Undang-undang Republik Indonesia No. 20 tahun 2003 tentang Sisdiknas yang sudah dikemukakan di atas, khususnya bab I tentang ketentuan umum pasal 1 ayat 14 dikatakan bahwa anak usia dini adalah anak yang berada pada rentang usia lahir sampai 6 tahun, sehingga di Indonesia anak yang telah berusia di atas 6 tahun sudah berada pada jalur pendidikan dasar (elementary school).

Dalam mengatasi perbedaan ini, maka di Indonesia pada anak yang duduk di kelas awal (kelas 1,2,3 Sekolah Dasar), Departemen Pendidikan dan Kebudayaan melalui Pusat Kurikulum (PUSKUR) mengeluarkan kebijakan tentang penggunaan pembelajaran tematik, yaitu proses pembelajaran yang dilakukan melalui tema-tema yang sesuai dengan tingkat pertumbuhan dan perkembangan anak usia 6-8 tahun.

Menurut Britton, anak usia dini adalah anak yang dimulai dari 0 sampai delapan tahun yaitu dimana dalam neuroscience dinyatakan bahwa pada masa itulah periode dimana sel-sel otak mengalami perkembangan cepat dan memiliki kemampuan menyerap berbagai macam stimulus dari luar dirinya. ${ }^{35}$ Hurlock menegaskan bahwa anak usia dini dimulai pada saat berakhirnya masa bayi yang penuh ketergantungan digantikan dengan tumbuhnya kemandirian dan berakhir ketika memasuki tahapan awal sekolah (dasar). ${ }^{36}$

Dilihat dari aspek perkembangan ilmu psikologi, anak usia dini berada dalam masa keemasan sepanjang rentang usia perkembangan anak. Usia keemasan merupakan masa yang disebut oleh Montessori dengan sensitive periode dimana anak mulai peka untuk menerima berbagai stimulasi dan berbagai upaya pendidikan dari lingkungannya baik disengaja maupun tidak disengaja. ${ }^{37}$ Pada masa peka inilah

\footnotetext{
${ }^{35}$ Lisley Britton, Montessory Play and Learn, a Parent Guide Purposeful Play From Two to Six (New York: Crown Publisher Inc., 1992), p. 12.

${ }^{36}$ Elizabeth B. Hurlock, Developmental Psychology (Tokyo: Mc-Graw Hill, 1978), p. 92.

37 Elizabeth Hainstock, Metode Pengajaran Montessori untuk Anak Prasekolah (Jakarta: Pustaka Delaprasta, 1999), p. 10.
} 
terjadi pematangan fungsi fisik dan psikis sehingga anak siap merespon terhadap stimulasi dan berbagai upaya-upaya pendidikan yang dirangsang oleh lingkungan.

Sedangkan berdasarkan aspek pedagogis, masa usia dini merupakan masa peletak dasar dan pondasi awal bagi pertumbuhan dan perkembangan selanjutnya. Untuk itu agar pertumbuhan dan perkembangan tercapai secara optimal, maka dibutuhkan situasi dan kondisi yang kondusif pada saat memberikan stimulasi dan upaya-upaya pendidikan yang sesuai dengan kebutuhan anak.

\section{Perkembangan Emosi Anak Usia Dini}

Emosi adalah suatu keadaan yang kompleks, dapat berupa perasaan ataupun getaran jiwa yang ditandai oleh perubahan biologis yang muncul menyertai terjadinya suatu perilaku. Aspek emosional melibatkan tiga variabel, yaitu variabel stimulus, variabel organismik dan variabel respons. Fungsi dan peranan emosi pada perkembangan anak adalah: 1) sebagai bentuk komunikasi dengan lingkungannya; 2) sebagai bentuk kepribadian dan penilaian anak terhadap dirinya; 3) sebagai bentuk tingkah laku yang dapat diterima lingkungannya; 4) sebagai pembentuk kebiasaan; 5) sebagai upaya pengembangan diri. ${ }^{38}$

Bacic emotion dan bentuk-bentuk emosi yang umum terjadi pada masa kanak-kanak adalah amarah, takut, cemburu, ingin tahu, iri hati, gembira, sedih dan kasih sayang. ${ }^{39}$ Ciri utama reaksi emosi pada anak adalah reaksi emosi anak yang sangat kuat, reaksi emosi sering kali muncul pada setiap peristiwa dengan cara yang diinginkan, reaksi emosi anak mudah berubah, reaksi emosi bersifat individual, reaksi emosi anak dapat dikenali melalui tingkah laku yang ditampilkan. ${ }^{40}$

Bentuk reaksi emosi pada anak akan tampak pada amarah yang muncul, ekspresi rasa takut, rasa malu, khawatir atau cemas, cemburu, rasa ingin tahu yang kuat, iri hati, senang, gembira, sedih dan kasih sayang. Gambaran umum pola atau bentuk hubungan emosi terhadap kehidupan seorang anak; Pertama, emosi mewarnai

\footnotetext{
38 Maurice J. Elias, Academic and Social Emotional Learning, www.ibe.unesco.org, p. 45

39 Ibid, p. 55

40 Ambron Sueann Robinson, Child Development, (New York: Holt Rinehart \& Winston, 1981), p. 221.
} 
pandangan anak terhadap dimensi kehidupan. Persepsi tentang rasa malu, takut, agresif, ingin tahu atau bahagia, dan lain-lain akan mengikuti pola tertentu sesuai pola yang berkembang dalam kelompok sosial dan kehidupannya. Kedua, mempengaruhi interaksi sosial. Melalui emosi, anak belajar cara mengubah perilaku agar dapat menyesuaikan diri dengan tuntutan dan ukuran sosial. Ketiga, reaksi emosional apabila diulang-ulang akan berkembang menjadi suatu kebiasan. ${ }^{41}$

Secara khusus perubahan emosi berakibat pada perilaku tertentu diantaranya adalah memperkuat semangat, apabila orang merasa senang atau puas atas hasil yang telah dicapai, dan melemahkan semangat, apabila timbul rasa kecewa karena kegagalan dan sebagai puncak dari keadaan ini adalah timbulnya rasa putus asa (frustrasi), menghambat atau mengganggu konsentarsi belajar, apabila sedang mengalami ketegangan emosi dan bisa juga menimbulkan sikap gugup (nervous) dan gagap dalam berbicara, mengganggu penyesuaian sosial, apabila terjadi rasa cemburu dan iri hati, suasana emosional yang diterima dan dialami individu semasa kecilnya akan mempengaruhi sikapnya di kemudian hari, baik terhadap dirinya sendiri maupun terhadap orang lain. ${ }^{42}$

Perkembangan emosi tidak selamanya stabil, banyak faktor yang mempengaruhi baik faktor yang berasal dari anak itu sendiri maupun yang berasal dari luar dirinya, baik pengaruhnya secara dominan, maupun secara terbatas. Adapun faktor yang mempengaruhi perkembangan emosi anak meliputi; keadaan di dalam diri individu, konflik-konflik dalam proses perkembangan, sebab-sebab yang bersumber dari lingkungan. ${ }^{43}$

Menurut Hurlock ada beberapa ciri khas emosi yang dimliki anak-anak diantaranya adalah: a) emosi yang kuat, b) emosi seringkali tampak, c). emosi bersifat

\footnotetext{
${ }^{41}$ Samsu Yusuf, Psikologi Perkembangan Anak \& Remaja (Bandung: Rosda Karya, 2002), p. 122.

${ }^{42}$ Robert E. Slavin, Educational Psychology, Theory and Practice (Boston: Allyn and Bacon, 1994), p. 195.

${ }^{43}$ Ibid, p. 334.
} 
sementara, d). reaksi mencerminkan individualitas, e). emosi berubah kekuatannya, f). emosi dapat diketahui melalui gejala perilaku. ${ }^{44}$

Dari uraian di atas, dapat disimpulkan bahwa terdapat tiga kondisi utama yang mempengaruhi perkembangan emosional anak yaitu; kondisi fisik, kondisi psikologis dan kondisi lingkungan. Apabila kondisi keseimbangan tubuh terganggu karena kelelahan, kesehatan yang buruk atau perubahan yang berasal dari perkembangan, anak akan mengalami emosi yang meninggi. Pengaruh psikologis yang penting adalah terkait dengan kerja intelligensi, aspirasi dan kecemasan sedangkan kondisi lingkungan seperti ketegangan terus-menerus dari lingkungan, jadwal yang ketat dan terlalu banyaknya pengalaman menggelisahkan yang merangsang anak secara berlebihan akan mengganggu perilaku emosional anak.

\section{PENUTUP}

Individu memiliki berbagai potensi, salah satunya adalah kecerdasan. Kecerdasan yang awalnya identik dengan kemampuan intelektual, kini berkembang menjadi sesuatu yang lebih luas dan kompleks, seperti seluas kecerdasan yang dibangun oleh Gardner. Gardner mengembangkan teori multiple intelligences, salah satu diantaranya adalah kecerdasan personal. Kecerdasan personal meliputi kecerdasan intrapersonal dan interpersonal, dalam hal ini dikenal oleh Goleman sebagai kecerdasan emosional.

Kecerdasan terkait dengan kemampuan individu dalam menyelesaikan masalah secara efektif dan efisien. Sedangkan emosi merupakan suatu keadaan perasaan yang kompleks yang mempengaruhi sistem psikofisis yang disertai warna afektif dan kecenderungan untuk bertindak.

Emosi sangat penting bagi rasionalitas, begitu pula sebaliknya rasionalitas memiliki peran eksekutif bagi emosi. Emosi dapat bersifat membahayakan manakala emosi tidak dibimbing oleh nalar. Tidak sedikit kasus yang memperlihatkan emosi

\footnotetext{
${ }^{44}$ Elizabeth B. Hurlock, op.cit., p.216.
} 
yang begitu liar karena sebuah kekecewaan ataupun ketakutan. Karena itu, keberhasilan hidup atau kesuksesan individu adalah manakala individu mampu menselaraskan kecerdasan rasional dan kecerdasan emosional.

Mengingat kedua kecerdasan memiliki peran masing-masing dan menentukan dalam keberhasilan hidup seorang anak kelak di kemudian hari, maka kecerdasan intelektual dan kecerdasan emosional mesti menjadi perhatian yang sama. Sementara saat ini dalam dunia akademik masih lebih banyak mengakomodasi kecerdasan intelektual. Begitu pula halnya dengan hasil pengukuran IQ yang tinggi menjadi hal yang penting. Karena pada dasarnya anak yang mengalami kekacauan emosional, tentu akan mengalami kesulitan berpikir dengan jernih. Hal ini akan berakibat kepada penurunan efektifitas belajar, karena anak yang resah, cemas atau gelisah tidak akan mampu berpikir dengan baik.

Dengan demikian, mengetahui kemampuan kecerdasan emosional anak sejak dini menjadi hal yang perlu untuk menunjang keberhasilan di sekolah.

\section{DAFTAR PUSTAKA}

Arce, Eve-Marie. 2000.Curriculum for Young Children: An Introduction. New York: Delmar Thomson Learning,

Anonymous. Emotional Intelligence. 2008 (http://www.Allpsych.com/dictionary /dictionary2.html).

.Emotional Intelligence. 2008 (http://www.En.wiktionary.org/ wiki/emotional.intelligence).

.Emotional Intelligence. 2008 (www.case.edu/med/epidbio/mphp439/ dictionary.htm). Emotional Intelligence, (http://Emotional_intelligence_wikipedia.htm).

Bar-On, Reuvan, 2009 The 5 Meta-Factors and 15 Sub-Factors of the Bar-On Model, (www.reuvenbaron.org).

Boyatzis, R., Daniel Goleman and K. Rhee, Clustering Competence in Emotional Intelligence: Insights from the Emotional Competence Inventory (ECI). In (www. wikipedia_emotional intelligence).

Britton, Lisley. 1992.Montessory Play and Learn, A Parent Guide Purposeful Play From Two to Six. New York: Crown Publisher Inc.,

Chaplin. 2011.Kamus Lengkap Psikologi, terjemahan Kartini Kartono. Jakarta: Raja Grafindo Persada. 
Cherniss, Cary, 2008 "Paper Annual Meeting of the Society for Industrial and Organizational Psychology: Emotional Intelligence: What it is and Why Matters". (www.eiconsortium.org).

Ciarrochi, Joseph, Joseph P. Forgas. and Jhon D. Mayer, (eds). 2001 Emotional Intellegence in Everyday Life A Scientific Inquiry. Philadelphia: Psychology Press,.

Cooper, Robert K. \& Ayman Sawaf. 1997. Executive EQ, Emotional Intelligence In Business. London, Orion.

Davis. Mark 2008. Test EQ Anda, terjemahan Michael Wong, Suharsono dan Khotimah. Jakarta: Mitra Media,

Direktorat PAUD. 2002.Tantangan yang Harus Dijawab. Jakarta: Buletin PADU Jurnal Ilmiah Anak Usia Dini

D. Wechsler, Non-Intellective Factors in General Intelligence, 2008 (www.eiconsortium.org).

Elias, J. Maurice. Academic and Social Emotional Learning, www.ibe.unesco.org.

Gardner, Howard. Kecerdasan Majemuk, Teori dan Praktek, terjemahan Alexander Sindoro. Jakarta: Interaksara, tanpa tahun.

. 1983.. Frames of Mind. New York: Basic Books,

Gibbs. Nancy, The EQ Factor, (www.timereports_undestandingpsychology).

Given, B. K. 2007.Brain-Based Teaching, Merancangkan Kegiatan BelajarMengajar yang Melibatkan Otak Emosional, Sosial, Kognitif, Kinestetis, dan Reflektif, terjemahan Lala Herawati Dharma. Bandung: Mizan

Goleman, Daniel. 2003.Emotional Intelligence, alihbahasa, Hermaya. Jakarta: Gramedia, . 1995.Emotional Intelligence Why It Can Matter More Than IQ. New York: Bantam Books, .2000.Kecerdasan Emosi untuk Mencapai Puncak Prestasi, terjemahan Alex Tri Kuntjoro. Jakarta: Gramedia Pustaka Utama,

Hagenhan B. R and Oslon J Matthew. 1997.An introduction to Theories of Learning. New Jersey: Prentice-Hill, Inc.,

Hainstock, Elizabeth. 1999.Metode Pengajaran Montessori untuk Anak Prasekolah, Jakarta: Pustaka Delaprasta,

Hurlock, Elizabeth B. 1978.Developmental Psychology. Tokyo: Mc-Graw Hill, Lefton. A. Lester. 1997.Psychology. Boston: Allyn \& Bacon,

Lodge, Ruper C. 1974.Philosophy of Education. New York: Harer and Brothers,

Mayer D. John, 2001.A Field Guide to Emotional Intelligence, in Joseph Ciarrochi, Joseph P. Forgas and John D. Mayer (Eds), Emotional Intelligence in Everyday Life A Scientific Inquiry, Philadelphia: Psychology Press,

Patton, P 2000.Development from Succses to Significance. Alih bahasa Hermes, Jakarta: Mitra Media,

Payne, W.L. 2008.A Study of Emotion: Developing Emotional Intelligence, Self Integration, Relating to Fear, Pain and Desire. (Dissertation Abstracts 
International: University Microfilms 47), (http//EI_artikel/Emotional_intelligence_wikipedia.htm).

Salovey, P. \& Mayer, J.D. Emotional Intelligence, 2009. (http://unh.edu/emotional_intelligence/EIAssets/EmotionalIntelligencePr oper/EI1990_Emotional_Imagination, Cognition, and Personality) . \& D. Grewal, The Science of Emotional Intelligence. Current Direction in Psychological Science, volume 4-6. In (www. wikipedia_emotional intelligence).

Slavin, Robert E. 1994.Educational Psychology Theory and Practice, Boston: Allyn and Bacon,

Stein, S \& Howard Book 2002.. Ledakan EQ, 15 Kecerdasan Emosional Meraih Sukses. Bandung: Kaifa,

Sueann, Ambron Robinson, 1981.Child Development, New York: Holt Rinehart \& Winston,

Syah, Muhibbin. 2000.Psikologi Pendidikan dengan Pendekatan Baru. Bandung: Rosda Karya,

Undang-undang Republik Indonesia Nomor 23 Tahun 2003 tentang Sistem Pendidikan Nasional.

Yusuf, Syamsu. 2002.Psikologi Perkembangan Anak dan Remaja. Bandung: Rosda Karya,

Zohar, D and Ian Marshall. 2000. Spiritual Intelligence The Ultimate Intelligence, London: Bloomsbury Publishing 